\title{
ANALYSIS OF INDICATORS OF DENTAL HEALTH'S ADULT POPULATION OF THE TRANSCARPATHIA REGION AND PROVIDING THEM SPECIALIZED MEDICAL CARE IN THE PUBLIC HEALTH SECTOR
}

\section{Pishkovtsi A.-M. M.}

\section{INTRODUCTION}

According to experts, oral health is one of the fundamental foundations of general human health. According to official WHO statistics, about $98 \%$ of people in the world suffer from inflammatory diseases of periodontal tissues. The incidence of caries is also almost $100 \%{ }^{1}$. In order to protect the dental health population, one of the most important goals is to control the European strategic organization of protecting the health by achieving good health for all ${ }^{2}$.

In 2003, the World Health Organization, together with the International Federation of Dentists, proposed new global goals for dental health for the period up to $2020^{3}$. Unlike previous global goals, which indicated specific numbers, there are no new goals for them, since the variability indicators of dental morbidity in the world does not allow to determine even approximate averaged indicators. WHO recommends the development of measurable dental health goals in each country based on proposed global goals by 2020 .

${ }^{1}$ Department of Health Statistics and Informatics, World Health Organization Information, Evidence and Research Group (2013) My`rovaya staty`sty ka 2013 [World Statistics 2013], Department of Health Statistics and Informatics, World Health Organization Information, Evidence and Research Group. Retrieved from: http://www.who.int/gho/publications/ world_health_statistics/2013/en/index.html. (accessed 18 November 2019)

${ }^{2}$ European Series on Health for All (2005) Osnovy politiki dostizheniya zdorovya dlya vseh v Evropejskom regione VOZ [Health for All Policy Framework for the WHO European Region]. European Series on Health for All (electronic journal) no. 7, 98 pp. Retrieved from: http://www.euro.who.int/ru/publications/abstracts/health21-the-health-for-all-policyframework-for-the-who-european-region (accessed 17 November 2019)

${ }^{3}$ FDI General Assembly (2003) Zayavlenie mezhdunarodnoj stomatologicheskoj associacii (FDI) «Globalnye celi v oblasti stomatologicheskogo zdorovya (Sovmestnoe zayavlenie FDI VOZ - IADR)» [Statement of the International Dental Association (FDI) «Global Dental Health Goals (Joint Statement of FDI-WHO-IADR)»]. FDI General Assembly. Retrieved from: http://www.e-stomatology.ru/star/ info/fdi/fdi_global. Htm (accessed 14 November 2019) 
The importance of dental health is also indicated by the fact that in 2013 the World Dental Federation FDI established the World Oral Health Day $(\mathrm{WOHD})^{4}$.

The current state of dental health of the population of Ukraine is characterized by a high prevalence of dental diseases, curtailment of preventive measures, and a reduction in government funding for the dental service ${ }^{5}$.

In Ukraine, the number of dentists (public and private dentistry) is 6.2 per 10 thousand people, including state ownership - 4.56 per 10 thousand. According to statistics from the Ministry of Health (MoH) of Ukraine, the majority of the population (> 80\%) receives dental care in public health institutions of state ownership ${ }^{6}$.

In most European countries, $80-85 \%$ of dentists are general practitioners. They work on the principle of a family doctor and, while treating the most common diseases of the teeth, oral cavity and maxillofacial region, they carry out preventive measures for adults and children. Only $15-20 \%$ of doctors provide specialized or highly specialized dental care. State programs for the prevention of dental diseases are developed and work ${ }^{7}$. In Ukraine, dental disease prevention programs have not been implemented.

After the introduction of the internship in Dentistry in 2006 in Ukraine, the share of dentists (general practitioners) grew to $70 \%$. The rest are doctors of specialization. In accordance with the existing qualification characteristics, the dentist performs the functions of a family dentist or general practitioner and must provide primary dental care, as well as carry out preventive measures on an outpatient basis.

However, organizationally this issue has not been resolved today. According to the current legislation, all dentists are legally assigned to the secondary level of medical care, although most of them work at the primary level of dental care.

A particularly difficult situation with dental care has developed in rural areas. After the dentist ceased to be present at the primary level, the mass

\footnotetext{
4 PII Vsemirnaya stomatologicheskaya federaciya [FDI World Dental Federation] Retrieved from:https://www.fdiworlddental.org/ (accessed 17 November 2019)

${ }^{5}$ Vahnenko O. M. (2011) Analiz resursnogo zabezpechennya stomatologichnoyi sluzhbi v Ukrayini [Analyze of resource care of dental service in Ukraine]. Modern dentistry,no. 3, pp. $172-176$.

${ }^{6}$ Yu.V.Voronenko, O.V.Pavlenko, I.P.Mazur (2018) Stomatologichna dopomoga $v$ Ukrayini: osnovni pokazniki diyalnosti za 2008-2018 roki [Dental auxiliaries in Ukraine: the main displays of activity in 2008-2018: pre-historic]. Kropivnitsky: Polium. (in Ukrainian)

${ }^{7}$ Kostlan Ya. (1982) Stomatologicheskoe obsluzhivanie v Evrope [Dental care in Europe] World Health Organization. European Regional Office. Copenhagen
} 
liquidation of dental offices and the reduction of dental positions began. There is no activity in the emergence of private dental offices, especially in remote villages, due to a lack of funds for the local population.

In 2017, the Verkhovna Rada of Ukraine adopted a number of laws aimed at changes in the health care system, in particular: "On amendments to some legislative acts of Ukraine regarding improvement of legislation on the activities of health care institutions ${ }^{8}$, , On state financial guarantees of public health services» ${ }^{9}$. The Ministry of Health of Ukraine announced the reform of the healthcare system, including the introduction of the principle "money goes for the patient", and a change in the principles of financing primary health care in $2018^{10}$.

The fundamentals of Ukrainian legislation on health care ${ }^{11}$ determine that primary medical care provides for counseling, diagnosis and treatment of the most common diseases, injuries, poisoning, pathological, physiological (during pregnancy) conditions, the implementation of preventive measures and referral in accordance with the medical indications of the patient, who does not need emergency medical care to provide him with secondary (specialized) or tertiary (high-specialist reshape the company), medical care and emergency medical care in the cases. According to the new edition of the third part of Art. 351 of the Fundamentals of the legislation of Ukraine on health care, primary care is provided by general

\footnotetext{
${ }^{8}$ Pro vnesennya zmin do deyakih zakonodavchih aktiv Ukrayini shodo udoskonalennya zakonodavstva z pitan diyalnosti zakladiv ohoroni zdorov'ya [On Introduction of Wetlands to the Actual Legislative Acts of Ukraine on Food and Nutrition Legislation on Health Protection]: Zakon Ukrayini vid 06.04.2017 r. № 2002 [Law of Ukraine no. 2002 of 06.04.2017]. Retrieved from:http://www.ukrainepravo.com/law-making/bill_passed_by_legislature/zakon-ukraini-provnesennya-zmin-do-deyakikh-zakonodavchikh-aktiv-ukraini-shchodo-udoskonalennya-zak/ (accessed 15 November 2019)

${ }^{9}$ Pro derzhavni finansovi garantiyi medichnogo obslugovuvannya naselennya [On Holders of Financial Guarantees for Medical Services to the Population]: Zakon Ukrayini vid 19 zhovtnya 2017 roku № 2168-VIII [Law of Ukraine No. 2168-VIII of June 19, 2017]. Retrieved from: http://search.ligazakon.ua/__doc2.nsf/link1/T172168.html (accessed 14 November 2019)

10 Pro zatverdzhennya Poryadku realizaciyi derzhavnih garantij medichnogo obslugovuvannya naselennya za programoyu medichnih garantij dlya pervinnoyi medichnoyi dopomogi na 2018 rik [On Approval of the Procedure for Realization of the Realization of the Population's Healthcare Guarantees for the Program of Medical Guarantees for Primary Medical Assistance for 2018]: Postanova KMU vid 25.04.2018 r. № 407 [Resolution of the Cabinet of Ministers of Ukraine No. 407 dated 25.04.2018]. Retrieved from: https://www.apteka.ua/article/458646 (accessed 13 November 2019)

${ }^{11}$ Osnovi zakonodavstva Ukrayini pro ohoronu zdorov'ya [On Healthy Hunting Legislation of Ukraine]: Zakon Ukrayini vid 19 listopada 1992 roku № 2801-XII [Law of Ukraine No. 2801-XII of November 19, 1992]. Retrieved from: https://zakon.rada.gov.ua/laws/show/280112 (accessed 17 November 2019)
} 
practitioners - family doctors and doctors of other specialties, defined by the central executive body that ensures the formation of state policy in the field of health care, and other medical workers working under their supervision. At the same time, dentists, in fact being the doctors of the first contact for patients with diseases of the teeth and maxillofacial region, are not assigned to primary care physicians in the country.

Based on the foregoing, it follows that the optimization of dental care for the population during the reform of the healthcare system requires an analysis of the level of dental health of the population and the existing dental care system.

\section{Analysis of adult dental health in Transcarpathian region}

The analysis of dental health of the adult population of Transcarpathian region and the provision of specialized dental care in the public health sector was carried out using data from the Department of Health of the Transcarpathian Regional State Administration for the period 2014$2018^{12,13,14,15,16}$.

When studying the dental health status of the adult population of the Transcarpathian region, the following indicators were studied and analyzed:

\footnotetext{
${ }^{12}$ Transcarpathian Regional Medical Information and Analytical Center (2015) Merezha zakladiv ta osnovni pokazniki diyalnosti sistemi ohoroni zdorov'ya Zakarpatskoyi oblasti za 2014 rik [The extent of laying and the main indicators of health care system of Transcarpathian region in 2014]. Uzhgorod: Transcarpathian Regional Medical Information and Analytical Center (in Ukrainian)

${ }^{13}$ Transcarpathian Regional Medical Information and Analytical Center (2016) Merezha zakladiv ta osnovni pokazniki diyalnosti sistemi ohoroni zdorov'ya Zakarpatskoyi oblasti za 2015 rik [The extent of laying and the main indicators of health care system of Transcarpathian region in 2015]. Uzhgorod: Transcarpathian Regional Medical Information and Analytical Center (in Ukrainian)

${ }^{14}$ Transcarpathian Regional Medical Information and Analytical Center (2017) Merezha zakladiv ta osnovni pokazniki diyalnosti sistemi ohoroni zdorov'ya Zakarpatskoyi oblasti za 2016 rik [The extent of laying and the main indicators of health care system of Transcarpathian region in 2016]. Uzhgorod: Transcarpathian Regional Medical Information and Analytical Center (in Ukrainian)

${ }^{15}$ Transcarpathian Regional Medical Information and Analytical Center (2018) Merezha zakladiv ta osnovni pokazniki diyalnosti sistemi ohoroni zdorov'ya Zakarpatskoyi oblasti za 2017 rik [The extent of laying and the main indicators of health care system of Transcarpathian region in 2017]. Uzhgorod: Transcarpathian Regional Medical Information and Analytical Center (in Ukrainian)

${ }^{16}$ Transcarpathian Regional Medical Information and Analytical Center (2019) Merezha zakladiv ta osnovni pokazniki diyalnosti sistemi ohoroni zdorov'ya Zakarpatskoyi oblasti za 2018 rik [The extent of laying and the main indicators of health care system of Transcarpathian region in 2018]. Uzhgorod: Transcarpathian Regional Medical Information and Analytical Center (in Ukrainian)
} 
the incidence of the adult population of the region for caries, periodontal disease, diseases of the mucous membrane of the cavity, as well as the prevalence of adult caries, periodontal disease and diseases of the oral mucosa per 10 thousand adult population of the area. All indicators are recorded on the basis of population overtures for dental medical care in public health institutions, so we can talk not about «objective data on the state of dental health» in the adult population of the region, but only about trends.

In the table. 1 shows data on prevalence rates among the adult population of the area of dental caries.

Table 1

The prevalence of dental caries among the adult population (per 10 thousand adults), 2014-2018

\begin{tabular}{|c|c|c|c|c|c|}
\hline Administrative territory & $\mathbf{2 0 1 4}$ & $\mathbf{2 0 1 5}$ & $\mathbf{2 0 1 6}$ & $\mathbf{2 0 1 7}$ & $\mathbf{2 0 1 8}$ \\
\hline Uzhgorod city & 24171,89 & 17036,23 & 13194,75 & 15975,25 & 15837,55 \\
\hline \multicolumn{6}{|c|}{ Districts } \\
\hline Beregovsky & 19042,14 & 18904,70 & 18404,72 & 84688,19 & 22290,31 \\
\hline Vinogradovsky & 8885,48 & 9898,59 & 13557,66 & 16541,84 & 12838,72 \\
\hline Velykyi Bereznyi & 9244,31 & 11920,27 & 10831,24 & 11378,74 & 15229,71 \\
\hline Volovetsky & 7077,43 & 17365,88 & 24880,10 & 8528,72 & 12688,99 \\
\hline Irshavsky & 14435,10 & 14012,98 & 14415,88 & 14003,88 & 14372,56 \\
\hline Mizhhirskyi & 11092,43 & 16231,27 & 12224,86 & 16772,10 & 20180,43 \\
\hline Mukachevo & 15819,12 & 15402,26 & 15908,43 & 22904,77 & 13569,24 \\
\hline Perechyn & 16345,09 & 27513,01 & 13290,19 & 19921,04 & 17017,03 \\
\hline Rakhiv & 19460,13 & 16593,45 & 17129,80 & 20160,80 & 19628,46 \\
\hline Svalyavsky & 21404,87 & 19786,17 & 23170,16 & 12192,68 & 19133,81 \\
\hline Tyachivsky & 17636,84 & 18268,45 & 28701,62 & 30214,37 & 42545,05 \\
\hline Uzhgorod & 13061,54 & 14689,08 & 15862,16 & 15564,80 & 16499,05 \\
\hline Khust & 17353,43 & 17637,82 & 18784,84 & 17612,69 & 19484,71 \\
\hline All over the region & 15130,14 & 15469,29 & 17749,40 & 20499,38 & 20405,60 \\
\hline
\end{tabular}

An analysis of the data in Table 1 showed that over the period of the study (2014-2018), the prevalence rate among the adult population of the area of dental caries increased 1.35 times and amounted to 20405.60 per 10 thousand population. The growth of this indicator was registered in 10 (71.43\%) of the administrative territories of the region. The highest levels of growth in prevalence among adults in the area of dental caries were recorded in Mizhhirskyi (1.82 times) and Tyachiv (2.41 times) districts. In the context of the administrative territories of the region, statistically significant differences of this indicator were recorded from 12688.99 in Volovetsky to 42545.05 per 10 thousand of the adult population in Tyachiv district. 
The next step in the study was to study the prevalence of adult periodontal disease in adults. The results are shown in table 2 .

Table 2

The prevalence of periodontal disease among the adult population (per 10 thousand adults), 2014-2018

\begin{tabular}{|c|c|c|c|c|c|}
\hline Administrative territory & $\mathbf{2 0 1 4}$ & $\mathbf{2 0 1 5}$ & $\mathbf{2 0 1 6}$ & $\mathbf{2 0 1 7}$ & $\mathbf{2 0 1 8}$ \\
\hline Uzhgorod city & 497,81 & 1690,41 & 2257,90 & 2060,64 & 2259,34 \\
\hline \multicolumn{5}{|c|}{ Districts } \\
\hline Beregovsky & 456,19 & 478,93 & 478,10 & 508,30 & 625,39 \\
\hline Vinogradovsky & 132,26 & 291,45 & 469,49 & 175,82 & 182,49 \\
\hline Velykyi Bereznyi & 265,08 & 496,09 & 337,51 & 164,29 & 225,59 \\
\hline Volovetsky & 524,55 & 3657,21 & 1972,35 & 412,19 & 377,09 \\
\hline Irshavky & 332,02 & 571,65 & 279,37 & 89,30 & 68,00 \\
\hline Mizhhirskyi & 81,52 & 215,90 & 219,50 & 193,74 & 454,11 \\
\hline Mukachevo & 243,28 & 335,75 & 256,78 & 102,21 & 30,65 \\
\hline Perechyn & 475,08 & 816,93 & 202,09 & 506,69 & 373,52 \\
\hline Rakhiv & 381,58 & 136,60 & 98,84 & 50,93 & 48,97 \\
\hline Svalyavsky & 1939,19 & 409,40 & 4382,85 & 2827,78 & 1426,25 \\
\hline Tyachivsky & 524,61 & 785,46 & 1763,14 & 4788,71 & 4005,44 \\
\hline Uzhgorod & 247,63 & 237,74 & 2092,12 & 565,49 & 553,70 \\
\hline Khust & 134,25 & 155,09 & 137,47 & 132,48 & 70,63 \\
\hline All over the region & 370,75 & 522,70 & 946,42 & 1186,59 & 1050,65 \\
\hline
\end{tabular}

According to the data given in table 2 shows that the prevalence rate among the adult population of the region during the observation (2014-2018) of periodontal disease increased by 2.83 times and amounted to 1050.65 per 10 thousand of the adult population with territorial marginal differences of 130.68 times. The lowest prevalence rate among the adult population of the area of periodontal disease (30.65) was recorded in Mukachevo, and the most (4005.44) in Tyachiv district. During the study period, a decrease in the prevalence rate of periodontal disease among adults in the region of periodontal disease was recorded in $8(57.14 \%)$ administrative territories, and its growth was recorded in $6(42.86 \%)$ administrative territories. At the same time, the highest level of decline in this indicator was recorded in Irshavsky (4.88 times), Mukachevo (7.94 times) and Rakhovsky (7.79 times) districts, and the highest level of growth of this indicator was recorded in Mizhhirskyi (5.57 times) and Tyachiv (7.64 times) districts. This situation is associated with different levels of access to dental care for the population, especially for those who live in remote areas.

In accordance with the research program, the next step was to study the prevalence among adults of the area of diseases of the oral mucosa in the dynamics of 2014-2018. The data obtained are given in table 3. 
Table 3

The prevalence among the adult population of the area of diseases of the oral mucosa (per 10 thousand adults), 2014-2018

\begin{tabular}{|c|c|c|c|c|c|}
\hline Administrative territory & 2014 & 2015 & 2016 & 2017 & 2018 \\
\hline Uzhgorod city & 255,87 & 128,33 & 235,72 & 293,40 & 460,81 \\
\hline \multicolumn{6}{|c|}{ Districts } \\
\hline Beregovsky & 23,70 & 9,13 & 12,57 & 27,58 & 50,37 \\
\hline Vinogradovsky & 76,54 & 89,21 & 123,91 & 78,35 & 77,03 \\
\hline Velykyi Bereznyi & 75,17 & 78,20 & 68,42 & 88,46 & 100,44 \\
\hline Volovetsky & 206,10 & 1933,87 & 486,07 & 422,70 & 336,56 \\
\hline Irshavsky & 85,56 & 100,02 & 89,62 & 85,01 & 70,04 \\
\hline Mizhhirskyi & 81,52 & 104,49 & 70,12 & 136,01 & 116,25 \\
\hline Mukachevo & 76,51 & 48,72 & 35,62 & 25,15 & 44,05 \\
\hline Perechyn & 32,06 & 52,05 & 31,79 & 65,80 & 83,39 \\
\hline Rakhiv & 143,80 & 21,06 & 21,38 & 18,26 & 26,01 \\
\hline Svalyavsky & 251,70 & 251,53 & 751,21 & 2121,33 & 2729,85 \\
\hline Tyachivsky & 119,65 & 125,11 & 149,90 & 146,54 & 127,41 \\
\hline Uzhgorod & 96,87 & 102,85 & 1676,65 & 511,70 & 296,12 \\
\hline Khust & 11,58 & 25,85 & 71,43 & 178,70 & 33,63 \\
\hline All over the region & 101,15 & 118,12 & 234,92 & 262,84 & 282,63 \\
\hline
\end{tabular}

Prevalence rates among adults of the oral mucosa (Table 3) increased 2.79 times during the observation years and amounted to 282.63 per 10 thousand adults of the region. At the same time, the limit indicators in the context of the administrative territories of the region fluctuate 104.95 times: from 26.01 in Rakhiv to 2729.85 per 10 thousand adults in the Svalyava district with an increase of the indicated indicator in the district in the years of study 10.85 times. This requires a special study to investigate the causes of the extremely high incidence of adult oral mucosal disease and the rapid rate of increase in the prevalence of the disease in the adult population.

Further, the indicators of morbidity of the adult population of the Transcarpathian region for major dental diseases were studied. Table 4 shows the data on the incidence of the adult population of dental caries.

According to table 4 shows that the incidence of adult population of the region for dental caries in the study period increased by 1.06 times and amounted to 7207,73 per 10 thousand adults. The marginal difference of the indicated indicator in the section of administrative territories makes 17,51 times: from 979,81 in Mukachevo to 17160,07 in Tyachivsky district. With an increase in the period of the study, the incidence of adult caries in the dental caries was registered in $7(50.0 \%)$ administrative territories of the region. 
Table 4

The incidence of adult dental caries in the region (per 10 thousand adults), 2014-2018

\begin{tabular}{|c|c|c|c|c|c|}
\hline Administrative territory & $\mathbf{2 0 1 4}$ & $\mathbf{2 0 1 5}$ & $\mathbf{2 0 1 6}$ & $\mathbf{2 0 1 7}$ & $\mathbf{2 0 1 8}$ \\
\hline Uzhgorod city & 4146,57 & 3946,88 & 3124,84 & 4171,09 & 4778,99 \\
\hline \multicolumn{5}{|c|}{ Districts } \\
\hline Beregovsky & 6545,06 & 5881,08 & 6428,91 & 22925,01 & 5422,74 \\
\hline Vinogradovsky & 5591,61 & 5746,90 & 5452,49 & 9855,75 & 7242,95 \\
\hline Velykyi Bereznyi & 4500,41 & 4490,10 & 4597,77 & 4364,52 & 4522,74 \\
\hline Volovetsky & 5232,25 & 5919,72 & 6119,55 & 3887,17 & 3848,74 \\
\hline Irshavsky & 9321,33 & 8850,41 & 9353,20 & 8974,33 & 8264,55 \\
\hline Mizhhirskyi & 5418,12 & 5809,96 & 5527,98 & 5854,26 & 4624,41 \\
\hline Mukachevo & 6574,32 & 4988,06 & 4569,22 & 1944,16 & 979,81 \\
\hline Perechyn & 4717,96 & 5112,70 & 4935,08 & 3835,30 & 4132,91 \\
\hline Rakhiv & 8078,56 & 8072,31 & 8098,89 & 9199,06 & 9350,63 \\
\hline Svalyavsky & 8166,11 & 8103,50 & 9592,50 & 5917,43 & 9156,20 \\
\hline Tyachivsky & 8431,32 & 7737,67 & 11684,34 & 12458,57 & 17160,07 \\
\hline Uzhgorod & 5795,66 & 7004,18 & 6054,74 & 5421,14 & 6210,49 \\
\hline Khust & 7187,32 & 7035,32 & 7121,19 & 7605,67 & 5924,52 \\
\hline All over the region & 6793,49 & 6488,33 & 6866,24 & 7626,66 & 7207,73 \\
\hline
\end{tabular}

Table 5

Adult incidence of periodontal disease

with the highest and lowest rates in terms of administrative territories (per 10 thousand adult population), 2014-2018

\begin{tabular}{|c|c|c|c|c|c|}
\hline Administrative territory & $\mathbf{2 0 1 4}$ & $\mathbf{2 0 1 5}$ & $\mathbf{2 0 1 6}$ & $\mathbf{2 0 1 7}$ & $\mathbf{2 0 1 8}$ \\
\hline Uzhgorod city & 85,40 & 391,63 & 534,73 & 538,03 & 681,76 \\
\hline \multicolumn{7}{|c|}{ Districts } \\
\hline Mukachevo & 101,11 & 108,73 & 73,75 & 8,68 & 2,21 \\
\hline Rakhiv & 158,41 & 66,45 & 46,73 & 23,24 & 23,33 \\
\hline Svalyavsky & 739,81 & 167,67 & 1814,51 & 1372,40 & 682,51 \\
\hline Tyachivsky & 250,79 & 332,68 & 717,77 & 1974,57 & 1615,55 \\
\hline Uzhgorod & 109,88 & 113,36 & 798,58 & 196,96 & 208,42 \\
\hline Khust & 55,60 & 61,86 & 52,12 & 57,21 & 21,48 \\
\hline All over the region & 166,47 & 219,24 & 366,12 & 441,46 & 371,11 \\
\hline
\end{tabular}

According to the data in table. 5 shows that the period of the study the incidence rate of adult population of the periodontal disease increased 2.23 times and amounted to 371.11 per 10 thousand population. Thus the marginal difference of the indicator in the section of administrative territories of the region fluctuates 731.0 times: from 2.21 in Mukachevo to 1615.55 in Tyachiv district. In the Tyachiv district this indicator increased 6.44 times during the study period: from 250.79 in 2014 to 1615.55 in 2018. 
Further, in table. 6 presents the study data on the incidence rates of the adult population of the region for diseases of the oral mucosa.

Table 6

The incidence of adult population of the region for diseases of the oral mucosa with the largest and smallest indicators in the section of administrative territories (per 10 thousand adult population), 2014-2018

\begin{tabular}{|c|c|c|c|c|c|}
\hline Administrative territory & $\mathbf{2 0 1 4}$ & $\mathbf{2 0 1 5}$ & $\mathbf{2 0 1 6}$ & $\mathbf{2 0 1 7}$ & $\mathbf{2 0 1 8}$ \\
\hline Uzhgorod city & 43,89 & 29,73 & 55,82 & 76,61 & 139,05 \\
\hline \multicolumn{5}{|c|}{ Districts } \\
\hline Beregovsky & 8,15 & 2,84 & 4,39 & 7,47 & 12,25 \\
\hline Mukachevo & 31,80 & 15,78 & 10,23 & 2,13 & 3,18 \\
\hline Rakhiv & 59,70 & 10,25 & 10,11 & 8,33 & 12,39 \\
\hline Svalyavsky & 96,03 & 103,02 & 311,00 & 1029,54 & 1306,33 \\
\hline Uzhgorod & 42,98 & 49,04 & 639,99 & 178,22 & 111,47 \\
\hline Khust & 4,80 & 10,31 & 27,08 & 77,17 & 10,23 \\
\hline All over the region & 45,42 & 49,54 & 90,88 & 97,79 & 99,83 \\
\hline
\end{tabular}

The analysis given in the table. 6 data on the incidence of diseases of the oral mucous membrane of the adult population of the region indicate that over the study period this indicator increased by 2.19 times and amounted to 99.83 per 10 thousand adult population (Ukraine 82.4). In the context of the administrative territories of the region, as in the analysis of other pathologies, significant statistical differences in the incidence rate of the adult population of diseases of the oral mucosa were revealed. So, its marginal difference is 410.79 times from 3.18 in Mukachevo to 1306.33 in Savelovsky district. When conducting an analysis of the incidence of the adult population, the Svalyavsky district is of particular interest since it recorded, over the years of research, the incidence rate of the adult population by diseases of the oral mucosa by 13.60 times.

Thus, the analysis indicates a deterioration in dental health in the adult population of Transcarpathian region

\section{Characteristics of the system of providing the population} with dental medical care for adults in the public health sector

At the first stage of the study, the provision of the adult population with the full-time posts of dentists per 10 thousand adults was studied. The study and analysis of this indicator was carried out in the context of the administrative territories of the region. The results are shown in table 7. 
Table 7

Adult availability of full-time positions of dental practitioners (per 10 thousand adults), 2014-2018

\begin{tabular}{|c|c|c|c|c|c|}
\hline Administrative territory & $\mathbf{2 0 1 4}$ & $\mathbf{2 0 1 5}$ & $\mathbf{2 0 1 6}$ & $\mathbf{2 0 1 7}$ & $\mathbf{2 0 1 8}$ \\
\hline Uzhgorod city & 3,21 & 3,06 & 3,08 & 3,11 & 3,23 \\
\hline \multicolumn{7}{|c|}{ Districts } \\
\hline Beregovsky & 3,08 & 3,01 & 3,08 & 3,10 & 3,11 \\
\hline Vinogradovsky & 3,25 & 3,13 & 3,24 & 3,24 & 3,48 \\
\hline Velykyi Bereznyi & 3,37 & 3,62 & 3,63 & 3,64 & 3,67 \\
\hline Volovetsky & 3,44 & 3,19 & 3,19 & 3,19 & 3,21 \\
\hline Irshavsky & 3,96 & 3,87 & 3,94 & 3,93 & 3,92 \\
\hline Mizhhirskyi & 3,50 & 3,23 & 3,24 & 3,24 & 1,32 \\
\hline Mukachevo & 4,08 & 3,70 & 3,00 & 1,15 & 1,02 \\
\hline Perechyn & 2,73 & 2,73 & 2,42 & 2,43 & 2,22 \\
\hline Rakhiv & 3,89 & 3,88 & 3,88 & 3,87 & 3,72 \\
\hline Svalyavsky & 3,79 & 3,68 & 3,69 & 3,69 & 3,70 \\
\hline Tyachivsky & 4,26 & 3,97 & 3,96 & 3,94 & 3,53 \\
\hline Uzhgorod & 2,30 & 2,29 & 2,78 & 2,44 & 2,19 \\
\hline Khust & 3,44 & 3,37 & 3,35 & 3,43 & 1,10 \\
\hline $\begin{array}{c}\text { Institutions of regional } \\
\text { subordination }\end{array}$ & 0,05 & 0,08 & 0,06 & 0,05 & 0,05 \\
\hline All over the region & 3,63 & 3,51 & 3,42 & 3,13 & 2,74 \\
\hline
\end{tabular}

The data in table 7 indicate that during the study period as a whole in the region the security of the adult population in full-time positions of dentists has decreased by 1.32 times and amounted to 2.74 per 10 thousand adult population. In terms of administrative territories of the region, the highest level of reduction of the positions of dental practitioners for the provision of medical care to the adult population was registered in the Mukachevo district in 4,0 times with an indicator of 1,02, in the Mizhhirskyi district in 2,65 times with an indicator of 1,32 and in the Khust district in 3,13 times with a score of 1.10. A statistically insignificant increase in the indicator of the availability of adult population to full-time positions of dentists was registered in the territory of $4(28.57 \%)$ administrative territories.

Further, the issue of staffing of staff positions of dentists for servicing adult population by individuals in the context of the administrative territories of the region was studied. The data obtained are shown in Table 8. 
Table 8

Staffing levels of dentists for serving adults by individuals, 2014-2018 (\%)

\begin{tabular}{|c|c|c|c|c|c|}
\hline Administrative territory & $\mathbf{2 0 1 4}$ & $\mathbf{2 0 1 5}$ & $\mathbf{2 0 1 6}$ & $\mathbf{2 0 1 7}$ & $\mathbf{2 0 1 8}$ \\
\hline Uzhgorod city & 93,22 & 100,00 & 100,00 & 100,00 & 100,00 \\
\hline \multicolumn{5}{|c|}{ Districts } \\
\hline Beregovsky & 94,59 & 95,83 & 94,52 & 94,52 & 49,32 \\
\hline Vinogradovsky & 95,73 & 96,46 & 100,00 & 100,00 & 95,24 \\
\hline Velykyi Bereznyi & 100,00 & 100,00 & 100,00 & 100,00 & 100,00 \\
\hline Volovetsky & 100,00 & 91,67 & 91,67 & 91,67 & 100,00 \\
\hline Irshavsky & 100,00 & 100,00 & 100,00 & 100,00 & 97,50 \\
\hline Mizhhirskyi & 100,00 & 100,00 & 100,00 & 100,00 & 100,00 \\
\hline Mukachevo & 98,73 & 99,07 & 100,00 & 97,01 & 100,00 \\
\hline Perechyn & 92,31 & 92,31 & 95,65 & 95,65 & 95,24 \\
\hline Rakhiv & 100,00 & 98,11 & 99,06 & 96,23 & 96,08 \\
\hline Svalyavsky & 100,00 & 96,72 & 96,72 & 100,00 & 100,00 \\
\hline Tyachivsky & 99,12 & 98,58 & 98,11 & 98,10 & 98,94 \\
\hline Uzhgorod & 100,00 & 100,00 & 88,41 & 96,72 & 100,00 \\
\hline Khust & 100,00 & 100,00 & 100,00 & 100,00 & 95,35 \\
\hline $\begin{array}{c}\text { Institutions of regional } \\
\text { subordination }\end{array}$ & 100,00 & 100,00 & 100,00 & 85,71 & 100,00 \\
\hline All over the region & 98,29 & 98,53 & 98,34 & 98,18 & 94,89 \\
\hline
\end{tabular}

The analysis is given in table. 8 of the data indicates that the level of staffing of full-time positions of dentists for servicing adult population by individuals in the region in the period 2014-2018 decreased by $3.40 \%$ and amounted to $94.89 \%$. In territory $7(50,0 \%)$ of administrative territories ia in establishments of regional subordination the level of staffing of full-time positions of doctors - dentists for service of adult population by individuals is $100 \%$. The lowest level of staffing of natural persons is registered in the Beregovsky district, where it is $49.32 \%$.

The next step was to study the dynamics of the proportion of adults covered by preventive dental examinations for the period 2014-2019, the results of which are shown in table 9.

The analysis is given in table 9 data indicate that during the study period, the proportion of adults covered by preventive dental examinations decreased by $3.56 \%$ to $20.79 \%$ (Ukraine $17.2 \%$ ). At the same time, the share of adult population covered by preventive dental examinations in the context of administrative territories of the region has significant differences and ranges from $1.87 \%$ in the Mukachevo district to $30.18 \%$ in Uzhgorod. The marginal difference of the indicator is 16.14 times. In general, the data obtained indicate that the population is not interested in visiting dentists with a preventive purpose, and on the other hand, that there is no preventive component in the activity of the dental service of the region. 
Table 9

\section{Percentage of adult population covered}

by preventive dental examinations, 2014-2018 (\%)

\begin{tabular}{|c|c|c|c|c|c|}
\hline Administrative territory & $\mathbf{2 0 1 4}$ & $\mathbf{2 0 1 5}$ & $\mathbf{2 0 1 6}$ & $\mathbf{2 0 1 7}$ & $\mathbf{2 0 1 8}$ \\
\hline Uzhgorod city & 17,15 & 23,17 & 23,68 & 26,11 & 30,18 \\
\hline \multicolumn{7}{|c|}{ Districts } \\
\hline Beregovsky & 4,63 & 4,02 & 5,29 & 7,95 & 8,69 \\
\hline Vinogradovsky & 21,14 & 19,27 & 20,43 & 21,33 & 19,45 \\
\hline Velykyi Bereznyi & 22,34 & 14,26 & 13,67 & 13,40 & 14,44 \\
\hline Volovetsky & 15,99 & 19,12 & 18,54 & 12,86 & 8,72 \\
\hline Irshavsky & 31,77 & 30,51 & 31,84 & 30,74 & 28,78 \\
\hline Mizhhirskyi & 37,19 & 38,41 & 48,10 & 34,90 & 24,58 \\
\hline Mukachevo & 14,60 & 8,52 & 13,14 & 1,77 & 1,87 \\
\hline Perechyn & 12,22 & 14,77 & 10,59 & 12,37 & 22,18 \\
\hline Rakhiv & 20,15 & 48,65 & 47,65 & 45,76 & 46,67 \\
\hline Svalyavsky & 1,38 & 10,32 & 10,36 & 12,21 & 10,38 \\
\hline Tyachivsky & 38,58 & 34,38 & 20,63 & 20,55 & 18,05 \\
\hline Uzhgorod & 44,37 & 47,68 & 37,50 & 34,26 & 37,64 \\
\hline Khust & 29,45 & 15,12 & 14,41 & 16,24 & 15,99 \\
\hline All over the region & 24,35 & 24,59 & 23,02 & 21,04 & 20,79 \\
\hline
\end{tabular}

A logical continuation of the study was the study of the proportion of the adult population requiring the results of preventive examinations of sanitation of the oral cavity. The data obtained are given in table 10 .

Table 10

The proportion of the adult population requiring oral sanitation, 2014-2018 (\% of those examined)

\begin{tabular}{|c|c|c|c|c|c|}
\hline Administrative territory & $\mathbf{2 0 1 4}$ & $\mathbf{2 0 1 5}$ & $\mathbf{2 0 1 6}$ & $\mathbf{2 0 1 7}$ & $\mathbf{2 0 1 8}$ \\
\hline Uzhgorod city & 89,56 & 86,42 & 84,72 & 79,45 & 70,87 \\
\hline \multicolumn{7}{|c|}{ Districts } \\
\hline Beregovsky & 37,14 & 48,50 & 69,49 & 75,23 & 67,30 \\
\hline Vinogradovsky & 59,38 & 62,50 & 57,44 & 60,56 & 58,18 \\
\hline Velykyi Bereznyi & 67,24 & 71,83 & 71,22 & 72,94 & 71,83 \\
\hline Volovetsky & 59,43 & 57,95 & 50,50 & 38,41 & 37,68 \\
\hline Irshavsky & 72,40 & 71,74 & 74,77 & 73,30 & 75,29 \\
\hline Mizhhirskyi & 78,82 & 85,01 & 72,74 & 89,25 & 70,92 \\
\hline Mukachevo & 88,57 & 8,26 & 88,54 & 91,49 & 100,00 \\
\hline Perechyn & 55,92 & 52,79 & 60,43 & 64,87 & 66,89 \\
\hline Rakhiv & 72,13 & 45,16 & 49,41 & 51,65 & 53,96 \\
\hline Svalyavsky & 102,61 & 54,16 & 93,65 & 38,83 & 54,16 \\
\hline Tyachivsky & 85,50 & 83,04 & 91,00 & 91,18 & 95,04 \\
\hline Uzhgorod & 93,98 & 90,73 & 92,90 & 90,72 & 83,59 \\
\hline Khust & 95,00 & 91,97 & 86,67 & 79,62 & 82,74 \\
\hline All over the region & 82,10 & 192,79 & 89,09 & 89,92 & 89,79 \\
\hline
\end{tabular}


It was found that the proportion of adults who, as a result of preventive examinations, required remediation as a whole in the region increased by $7.69 \%$ and amounted to $89.79 \%$ of the number of surveyed (Ukraine $55.4 \%$ ). In terms of administrative territories of the region, this indicator ranged from $37.68 \%$ in the Volovetsky district to $100 \%$ in the Mukachevo district. The marginal difference of the indicator is 2.65 times.

In order to study the effectiveness of dental preventive examinations, the proportion of the adult population was further examined by the results of the prophylactic examination, which, according to the testimony, was the rehabilitation of the oral cavity. The data obtained are shown in Table 11.

Table 11

The proportion of the adult population who underwent rehabilitation of the oral cavity, 2014-2018 (\% of those in need)

\begin{tabular}{|c|c|c|c|c|c|}
\hline Administrative territory & $\mathbf{2 0 1 4}$ & $\mathbf{2 0 1 5}$ & $\mathbf{2 0 1 6}$ & $\mathbf{2 0 1 7}$ & $\mathbf{2 0 1 8}$ \\
\hline Uzhgorod city & 78,89 & 80,73 & 82,42 & 95,95 & 93,05 \\
\hline \multicolumn{7}{|c|}{ Districts } \\
\hline Beregovsky & 92,26 & 90,31 & 83,74 & 72,26 & 81,95 \\
\hline Vinogradovsky & 95,18 & 95,73 & 92,54 & 93,41 & 94,73 \\
\hline Velykyi Bereznyi & 73,27 & 81,09 & 82,16 & 84,92 & 81,09 \\
\hline Volovetsky & 86,47 & 82,25 & 81,44 & 95,47 & 83,25 \\
\hline Irshavsky & 80,23 & 82,67 & 83,63 & 82,70 & 85,09 \\
\hline Mizhhirskyi & 73,78 & 73,38 & 71,99 & 67,21 & 100,00 \\
\hline Mukachevo & 94,54 & 100,0 & 91,04 & 86,54 & 87,19 \\
\hline Perechyn & 60,55 & 60,95 & 63,57 & 75,89 & 61,12 \\
\hline Rakhiv & 74,22 & 85,00 & 86,34 & 77,78 & 75,91 \\
\hline Svalyavsky & 94,91 & 91,76 & 65,29 & 98,93 & 78,81 \\
\hline Tyachivsky & 88,17 & 87,69 & 95,00 & 94,71 & 94,45 \\
\hline Uzhgorod & 96,61 & 95,83 & 93,24 & 91,15 & 87,86 \\
\hline Khust & 83,96 & 92,05 & 89,12 & 84,31 & 80,36 \\
\hline All over the region & 84,99 & 85,76 & 82,86 & 85,10 & 81,07 \\
\hline
\end{tabular}

Obtained in the course of the study and given in table 11 data indicate that the proportion of adults from the needy, who, according to the results of a preventive examination, performed oral remediation in the years of the study (2014-2918) in the region decreased by $3.92 \%$ and amounted to 81 , $07 \%$. The decrease in the proportion of the population that underwent oral cavity repair in the years of the study decreased in 7 (50.0\%) administrative territories and the proportion of the corresponding adult population also increased in $7(50.0 \%)$ administrative territories of the region. The lowest proportion of the population who underwent oral remediation was registered in the Perechyn district $-61.12 \%$. 
An important indicator of the activity of the dental service is the indicator of the public's appeal to dentists. We studied the indicator of the population of the Transcarpathian region to the dentists in the dynamics of 2014-2018, per 10 thousand adults. The results obtained are shown in table 12 .

Table 12

The appeal of the adult population to dentists, 2014-2018 (per 10 thousand adults)

\begin{tabular}{|c|c|c|c|c|c|}
\hline Administrative territory & $\mathbf{2 0 1 4}$ & $\mathbf{2 0 1 5}$ & $\mathbf{2 0 1 6}$ & $\mathbf{2 0 1 7}$ & $\mathbf{2 0 1 8}$ \\
\hline Uzhgorod city & 4412,76 & 4224,83 & 4412,75 & 4714,44 & 5399,75 \\
\hline \multicolumn{7}{|c|}{ Districts } \\
\hline Beregovsky & 6888,76 & 5947,55 & 6846,67 & 6564,98 & 6033,19 \\
\hline Vinogradovsky & 8144,16 & 7471,00 & 7882,95 & 7919,91 & 7205,79 \\
\hline Velykyi Bereznyi & 9110,13 & 6807,82 & 7091,00 & 6633,06 & 6894,38 \\
\hline Volovetsky & 8544,60 & 8838,92 & 8517,00 & 8051,62 & 6836,99 \\
\hline Irshavsky & 11978,38 & 11602,71 & 11668,20 & 11210,84 & 9998,56 \\
\hline Mizhhirskyi & 7735,97 & 7753,03 & 8224,70 & 7748,55 & 5368,09 \\
\hline Mukachevo & 9716,64 & 6985,04 & 5694,07 & 2102,66 & 1742,34 \\
\hline Perechyn & 6809,83 & 6547,52 & 6635,75 & 5377,11 & 6718,14 \\
\hline Rakhiv & 7491,86 & 7545,52 & 7267,07 & 7873,28 & 8001,31 \\
\hline Svalyavsky & 8743,95 & 8194,93 & 7866,99 & 7586,92 & 7365,51 \\
\hline Tyachivsky & 5203,57 & 4721,73 & 7870,70 & 7820,67 & 5569,61 \\
\hline Uzhgorod & 8401,74 & 8324,01 & 6870,55 & 5982,87 & 6028,54 \\
\hline Khust & 6846,26 & 8280,93 & 7770,59 & 7689,18 & 4714,87 \\
\hline All over the region & 7800,08 & 7286,63 & 7463,20 & 6787,95 & 5911,84 \\
\hline
\end{tabular}

The analysis of the data presented in Table 12 indicates a decrease in the indicator of adult treatment of dentists in terms of 10 thousand adults in the years of the study by 1.32 times with the level of 5911.84 (Ukraine 7000). At the same time, the decrease in the rate of referral of adult population to dentists was registered in the territory of 10 (71.4\%) administrative territories. It should be noted that this indicator has statistically significant differences in the section of administrative territories of the region. Thus, the marginal difference in the rate of adult treatment of dentists is 5.74 times: from 1742.34 in Mukachevo to 9998.56 in the Irshava district.

Further, in table 13 presents the results of the study on the number of primary referrals of adults to dentists in terms of 10 thousand adults for the period 2014-2018. 
Table 13

Number of primary referrals of adults to dentists, 2014-2018 (per 10 thousand adults)

\begin{tabular}{|c|c|c|c|c|c|}
\hline Administrative territory & $\mathbf{2 0 1 4}$ & $\mathbf{2 0 1 5}$ & $\mathbf{2 0 1 6}$ & $\mathbf{2 0 1 7}$ & $\mathbf{2 0 1 8}$ \\
\hline Uzhgorod city & 1715,45 & 2316,76 & 2368,24 & 2610,97 & 3017,51 \\
\hline \multicolumn{7}{|c|}{ Districts } \\
\hline Beregovsky & 3437,15 & 3110,91 & 3493,08 & 2706,99 & 2432,78 \\
\hline Vinogradovsky & 6292,98 & 5805,78 & 4054,93 & 5958,08 & 5641,49 \\
\hline Velykyi Bereznyi & 4868,30 & 3766,78 & 4244,92 & 3835,68 & 2969,68 \\
\hline Volovetsky & 7392,87 & 3408,83 & 2459,62 & 4557,74 & 3033,14 \\
\hline Irshavsky & 6457,41 & 6315,87 & 6488,12 & 6408,46 & 5750,23 \\
\hline Mizhhirskyi & 4884,52 & 3579,48 & 4521,92 & 3490,48 & 2291,53 \\
\hline Mukachevo & 4155,94 & 3238,53 & 2872,20 & 848,80 & 722,08 \\
\hline Perechyn & 2886,47 & 1858,28 & 3713,32 & 1925,25 & 2428,69 \\
\hline Rakhiv & 4151,34 & 4864,75 & 4727,95 & 4562,85 & 4763,81 \\
\hline Svalyavsky & 3815,07 & 4095,54 & 4140,02 & 4853,27 & 4785,35 \\
\hline Tyachivsky & 4780,51 & 4235,54 & 4070,97 & 4123,39 & 4033,39 \\
\hline Uzhgorod & 4437,19 & 4768,29 & 3817,10 & 3482,95 & 3764,15 \\
\hline Khust & 4141,73 & 3988,77 & 3790,93 & 4318,29 & 3040,60 \\
\hline All over the region & 4490,04 & 4194,33 & 3952,64 & 3801,21 & 3532,23 \\
\hline
\end{tabular}

According to the results obtained during the study on the table. 13 data show that the number of primary appeals to the adult dentists for the period of the study decreased by 1.27 times and amounted to 3532.23 per 10 thousand adults, which is $59.75 \%$ of all appeals to the population for dental care (Ukraine 33,3\%). During the study period, the number of primary referrals of adults to dentists per 10 thousand adults decreased by 11 (\%) administrative territories of the region. In the context of administrative territories, this indicator differs 7.96 times: from 722.08 in Mukachevo district to 5750.23 in Irshava district.

The next step of the study was to study and analyze the function of the position of dentists, providing outpatient medical care to adults in terms of occupied position for the period 2014-2018. The results are shown in table 14. 
Table 14

Function of the position of dental practitioners providing outpatient medical care to adults, 2014-2018 (in terms of occupied position)

\begin{tabular}{|c|c|c|c|c|c|}
\hline Administrative territory & $\mathbf{2 0 1 4}$ & $\mathbf{2 0 1 5}$ & $\mathbf{2 0 1 6}$ & $\mathbf{2 0 1 7}$ & $\mathbf{2 0 1 8}$ \\
\hline Uzhgorod city & 1476,91 & 1380,46 & 1434,14 & 1516,54 & 1669,83 \\
\hline \multicolumn{5}{|c|}{ Districts } \\
\hline Beregovsky & 2367,37 & 2064,23 & 2350,49 & 2243,13 & 3939,00 \\
\hline Vinogradovsky & 2620,96 & 2477,36 & 2433,61 & 2447,73 & 2172,07 \\
\hline Velykyi Bereznyi & 2702,71 & 1879,87 & 1953,33 & 1824,53 & 1879,87 \\
\hline Volovetsky & 2484,77 & 3022,91 & 2914,36 & 2750,73 & 2132,00 \\
\hline Irshavsky & 3028,13 & 2994,68 & 2963,33 & 2853,53 & 2613,98 \\
\hline Mizhhirskyi & 2209,33 & 2399,15 & 2538,81 & 2389,19 & 4072,63 \\
\hline Mukachevo & 2413,23 & 1903,20 & 1895,25 & 1879,32 & 1708,20 \\
\hline Perechyn & 2698,17 & 2595,00 & 2861,82 & 2315,09 & 3184,40 \\
\hline Rakhiv & 1927,47 & 1982,73 & 1889,71 & 2112,51 & 2240,04 \\
\hline Svalyavsky & 2306,79 & 2302,92 & 2205,42 & 2054,69 & 1991,34 \\
\hline Tyachivsky & 1232,39 & 1207,41 & 2023,98 & 2020,83 & 1594,99 \\
\hline Uzhgorod & 3648,77 & 3632,77 & 2798,23 & 2533,08 & 2749,45 \\
\hline Khust & 1988,30 & 2458,18 & 2321,92 & 2242,72 & 4497,76 \\
\hline $\begin{array}{c}\text { Institutions of regional } \\
\text { subordination }\end{array}$ & 2417,56 & 2136,77 & 2590,18 & 3004,22 & 2549,80 \\
\hline All over the region & 2185,90 & 2107,62 & 2216,30 & 2208,64 & 2270,48 \\
\hline
\end{tabular}

According to the data in table 14. As a whole, in the region, the function of the position of dental practitioners providing outpatient medical care to the adult population increased by 84.58 medical procedures and amounted to 2270.48 in terms of the occupied position. The greatest increase in the function of the post was registered in Khust district - 2.3 times with the level of 4497.76. The decrease in the function of the post was registered in the territory of $7(50.0 \%)$ territories, and its increase in the territory of $7(50.0 \%)$ of administrative territories.

\section{CONCLUSIONS}

Analysis of dental health indicators of adults in the Transcarpathian region revealed its deterioration over the 2014-2018 period. During the study period, the incidence of both the incidence of the adult population and the prevalence of dental diseases among him. At the same time, the organization and delivery of specialized medical care in the public health sector tend to deteriorate.

\section{SUMMARY}

The conducted analysis of dental health indicators of adult population of Transcarpathian region showed its deterioration for the period 2014-2018. 
Thus, the incidence rates of adult population for dental caries increased by 1.06 times and amounted to 7207.73 , for periodontal disease increased by 2.23 times and amounted to 371.11 , for diseases of the oral mucosa indicates that during the study period specified the figure increased by 2.19 times and amounted to 99.83 per 10 thousand adults with a national figure of 82.4. Prevalence rates among adults among the adult population of dental caries increased 1.35 times and amounted to 20405.60, periodontal disease increased 2.83 times and amounted to 1050.65 , diseases of the oral mucosa increased 2.79 times and amounted to 282, 63 per 10 thousand adult population of the region. The incidence rates of the adult population of the Transcarpathian region and the prevalence of dental diseases studied in the cross section of administrative territories have significant statistical differences.

The analysis of the provision of specialized medical care to the public in the public health sector showed its deterioration, including the reduction: the provision of adult population to full-time positions of dentists by 1.32 times with a level of 2.74 per 10 thousand adults, completeness. staff positions of dentists to serve adults by individuals by $3.40 \%$ with a level of $94.89 \%$, coverage by preventive dental examinations by $3.56 \%$ with a level of $20.79 \%$, the proportion of adults in need, as According to the results of the prophylactic examination, the oral cavity was rehabilitated by $3.92 \%$ with the level of $81.07 \%$, the appeal of the adult population to dentists was 1.32 times in terms of 10 thousand with the level of 5911.84. There are statistically significant differences in the level of security of the adult population of the Transcarpathian region with the positions of dental practitioners and the indicators of the activity investigated by administrative territories.

The results obtained should be taken into account in the process of reforming the system of health care delivery to the population of the region.

\section{REFERENCES}

1. Department of Health Statistics and Informatics, World Health Organization Information, Evidence and Research Group (2013) My'rovaya staty`sty $k a 2013$ [World Statistics 2013], Department of Health Statistics and Informatics, World Health Organization Information, Evidence and Research Group. Retrieved from: http://www.who.int/gho/publications/ world_health_statistics/2013/en /index.html. (accessed 18 November 2019)

2. European Series on Health for All (2005) Osnovy politiki dostizheniya zdorovya dlya vseh v Evropejskom regione VOZ [Health for All Policy Framework for the WHO European Region]. European Series on 
Health for All (electronic journal) no. 7, 98 pp. Retrieved from: http://www.euro.who.int/ru/publications/abstracts/health21-the-health-forall-policy-framework-for-the-who-european-region (accessed 17 November 2019)

3. FDI General Assembly (2003) Zayavlenie mezhdunarodnoj stomatologicheskoj associacii (FDI) «Globalnye celi v oblasti stomatologicheskogo zdorovya (Sovmestnoe zayavlenie FDI - VOZ IADR)» [Statement of the International Dental Association (FDI) «Global Dental Health Goals (Joint Statement of FDI-WHO-IADR)»]. FDI General Assembly. Retrieved from: http://www.e-stomatology.ru/star/ info/fdi/fdi_global. Htm (accessed 14 November 2019)

4. PII Vsemirnaya stomatologicheskaya federaciya [FDI World Dental Federation] Retrieved from:https://www.fdiworlddental.org/ (accessed 17 November 2019)

5. Vahnenko O. M. (2011) Analiz resursnogo zabezpechennya stomatologichnoyi sluzhbi v Ukrayini [Analyze of resource care of dental service in Ukraine]. Modern dentistry,no. 3, pp.172-176.

6. Yu.V.Voronenko, O.V.Pavlenko, I.P.Mazur (2018) Stomatologichna dopomoga v Ukrayini: osnovni pokazniki diyalnosti za 2008-2018 roki [Dental auxiliaries in Ukraine: the main displays of activity in 2008-2018: pre-historic]. Kropivnitsky: Polium. (in Ukrainian)

7. Kostlan Ya. (1982) Stomatologicheskoe obsluzhivanie v Evrope [Dental care in Europe] World Health Organization. European Regional Office. Copenhagen.

8. Pro vnesennya zmin do deyakih zakonodavchih aktiv Ukrayini shodo udoskonalennya zakonodavstva $\mathrm{z}$ pitan diyalnosti zakladiv ohoroni zdorov'ya [On Introduction of Wetlands to the Actual Legislative Acts of Ukraine on Food and Nutrition Legislation on Health Protection]: Zakon Ukrayini vid 06.04.2017 r. № 2002 [Law of Ukraine no. 2002 of 06.04.2017]. Retrieved from: http://www.ukrainepravo.com/lawmaking/bill_passed_by_legislature/zakon-ukraini-pro-vnesennya-zmin-dodeyakikh-zakonodavchikh-aktiv-ukraini-shchodo-udoskonalennya-zak/ (accessed 15 November 2019)

9. Pro derzhavni finansovi garantiyi medichnogo obslugovuvannya naselennya [On Holders of Financial Guarantees for Medical Services to the Population]: Zakon Ukrayini vid 19 zhovtnya 2017 roku № 2168-VIII [Law of Ukraine No. 2168-VIII of June 19, 2017]. Retrieved from: http://search.ligazakon.ua/1_doc2.nsf/link1/T172168.html (accessed 14 November 2019) 
10. Pro zatverdzhennya Poryadku realizaciyi derzhavnih garantij medichnogo obslugovuvannya naselennya za programoyu medichnih garantij dlya pervinnoyi medichnoyi dopomogi na 2018 rik [On Approval of the Procedure for Realization of the Realization of the Population's Healthcare Guarantees for the Program of Medical Guarantees for Primary Medical Assistance for 2018]: Postanova KMU vid 25.04.2018 r. № 407 [Resolution of the Cabinet of Ministers of Ukraine No. 407 dated 25.04.2018]. Retrieved from: https://www.apteka.ua/article/458646 (accessed 13 November 2019)

11. Osnovi zakonodavstva Ukrayini pro ohoronu zdorov'ya [On Healthy Hunting Legislation of Ukraine]: Zakon Ukrayini vid 19 listopada 1992 roku № 2801-XII [Law of Ukraine No. 2801-XII of November 19, 1992]. Retrieved from: https://zakon.rada.gov.ua/laws/show/2801-12 (accessed 17 November 2019)

12. Transcarpathian Regional Medical Information and Analytical Center (2015) Merezha zakladiv ta osnovni pokazniki diyalnosti sistemi ohoroni zdorov'ya Zakarpatskoyi oblasti za 2014 rik [The extent of laying and the main indicators of health care system of Transcarpathian region in 2014]. Uzhgorod: Transcarpathian Regional Medical Information and Analytical Center (in Ukrainian)

13. Transcarpathian Regional Medical Information and Analytical Center (2016) Merezha zakladiv ta osnovni pokazniki diyalnosti sistemi ohoroni zdorov'ya Zakarpatskoyi oblasti za 2015 rik [The extent of laying and the main indicators of health care system of Transcarpathian region in 2015]. Uzhgorod: Transcarpathian Regional Medical Information and Analytical Center (in Ukrainian)

14. Transcarpathian Regional Medical Information and Analytical Center (2017) Merezha zakladiv ta osnovni pokazniki diyalnosti sistemi ohoroni zdorov'ya Zakarpatskoyi oblasti za 2016 rik [The extent of laying and the main indicators of health care system of Transcarpathian region in 2016]. Uzhgorod: Transcarpathian Regional Medical Information and Analytical Center (in Ukrainian)

15. Transcarpathian Regional Medical Information and Analytical Center (2018) Merezha zakladiv ta osnovni pokazniki diyalnosti sistemi ohoroni zdorov'ya Zakarpatskoyi oblasti za 2017 rik [The extent of laying and the main indicators of health care system of Transcarpathian region in 2017]. Uzhgorod: Transcarpathian Regional Medical Information and Analytical Center (in Ukrainian)

16. Transcarpathian Regional Medical Information and Analytical Center (2019) Merezha zakladiv ta osnovni pokazniki diyalnosti sistemi 
ohoroni zdorov'ya Zakarpatskoyi oblasti za 2018 rik [The extent of laying and the main indicators of health care system of Transcarpathian region in 2018]. Uzhgorod: Transcarpathian Regional Medical Information and Analytical Center (in Ukrainian)

Information about the author: Pyshkivtsi A.-M. M., orcid.org/0000-0002-6478-1948 Postgraduate student of the Department of Health Sciences

Uzhhorod National University 29, Mytna str., 88000, Uzhhorod, Ukraine 